\section{Førerkort og anfall med bevissthetstap}

I Tidsskriftet nr. 13-14/2011 gir Rasmus Lossius og medarbeidere synspunkter på EUs førerkortdirektivs bestemmelser om epilepsi, og implementering av dette i norske forskrifter og retningslinjer (1). Vi ville gjerne oppklart uklarhetene som påpekes, korrigert feiloppfatninger og forklart valg ved implementering av direktivet. Vi er kun gitt plass til korrespondanseinnlegg, så i korthet dette.

Forskriftens karenstider etter anfall er ikke endret som følge av direktivet.

Både for utredende leger og for oss som behandler førerkortsakene, er det ofte usikkert om det er epilepsi eller annen årsak til «anfall». Forskriften omfatter alle typer anfall med trafikksikkerhetsrelevans.

Begrepsbruken i attester, epikriser og journalkopier er ofte upresis. Veiledningene må ta hensyn til vanlige usikkerhetsmomenter.

Vi er enig $i$ at det er uheldig at EU-direktivets definisjon av epilepsi avviker fra definisjonen til International League of Epilepsy (ILAE). Ett klassisk GTK-anfall er ikke «epileptisk» i direktivets språkbruk. Det er jo likevel ingen synkope. Utredning og residivvurdering er som ved epilepsi. Vi har brukt betegnelsen «epileptiformt», for å skille fra synkoper og for at også enkeltstående, epilepsiliknende anfall skal omfattes. Bedre forslag?

Direktivteksten egner seg ikke som forskrift. Så vidt vi vet bruker de fleste land direktivet som utgangspunkt for nasjonale forskrifter og retningslinjer. Det har Norge også gjort.

Vi er enig i at det er en innskjerping når direktivet gir kjøreforbud fra nedtrappingsstart og i seks måneder etter seponering $\mathrm{av}$ antiepileptika. Vi kan dessverre ikke se at direktivet gir anledning til å «skjønne» at tre måneder burde holde (1). Det er riktig at meldeplikt ikke blir omtalt i direktivet. Håndhevelsesforhold reguleres nasjonalt. I en tysk undersøkelse var pasientenes etterlevelse av muntlig kjøreforbud $0 \%$ (2). Meldeplikt må antas å ha en trafikksikkerhetsfunksjon.

Direktivet aksepterer ikke at innehavere av klasse C eller D har > $\%$ årlig anfallsrisiko. Vi har presisert at et slikt estimat vanskelig kan gjøres for enkeltindivider (3). Tallet $2 \%$, som EU har valgt, kommer fra beregninger av akseptabel relativ risiko for ulykke, skadepotensial for tunge og lette biler, tid i trafikken og risikoen for at et anfall skal føre til ulykke (4). Forutsetninger og utregninger kan diskuteres.

Forfatterne ønsker mer fleksible dispensasjonsbestemmelser. Det reviderte EUdirektivet er detaljert. Det gir mindre rom for skjønn. Fordelen er forutsigbarhet og likebehandling. Ulempen er «stivbenthet». Attestutsteders oppgave er å gi korrekte opplysninger og vurdere anfallsrisiko.
Endringene i norsk førerkortforskrift som følge av EU-direktivet, var på høring. Når det likevel oppdages uklarheter i ettertid, ser vi gjerne at det tas direkte kontakt.

\section{Torkel Steen \\ Arne-Birger Knapskog \\ Helsedirektoratet}

Torkel Steen (f.1963) er overlege ved Hjerteavdelingen, Oslo universitetssykehus, Ullevål og har en bistilling i Helsedirektoratet

i fagområdet førerkortmedisin.

Ingen oppgitte interessekonflikter.

Arne-Birger Knapskog (f. 1937) er lege og seniorrådgiver i Helsedirektoratet.

Ingen oppgitte interessekonflikter.

\section{Litteratur}

1. Lossius R, Nakken KO, Brodtkorb E. Endrede helsekrav for førerkort ved epilepsi. Tidsskr Nor Legeforen 2011; 131: 1283-4.

2. Maas R, Venturo R, Kretschmar Cet al. Syncope, driving regulations and clinical reality: a survey of patients. BMJ 2003; 326: 21

3. Regler og veiledning for utfylling av helseattest for førerkort - IS-1437. www. helsedirektoratet.no/ publikasjoner/veiledere/f rerkort regler og veiledning_for_utfylling_av_helseattest_for_ f_rerkort_68087 (13.7.2011)

4. Epilepsy and driving in Europe. A report of the Second European Working Group on Epilepsy and Driving. http://ec.europa.eu/transport/ road_safety/behavior/doc/epilepsy_and_driving in_europe_final_report_v2_en.pdf (13.7.2011).

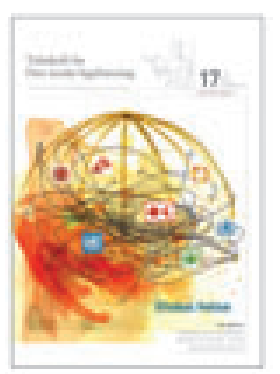

\section{Helsetjenesten for palestinere}

Jeg takker Tone Aarholt Hegna for den betimelige artikkelen i Tidsskriftet nr. 17/2011 om spesialisthelsetjenesten for palestinere (1). Som hun påpeker er den israelske okkupasjonen blitt en helt spesiell utfordring for det palestinske helsevesenet. Problemene henger sammen med administrative så vel som fysiske hindringer. Situasjonen forverres så å si fra dag til dag på grunn av den israelske bosettingspolitikken i de okkuperte områdene. Denne politikken har som mål å «endre fakta på bakken», noe man i vesentlig grad har oppnådd. Det situasjonskartet som medfølger Hegnas artikkel, er derfor misvisende. «Vestbredden» er i dag ikke lenger et sammen- hengende hele, men oppstykket av israelske bosettinger med veier og gjerder av forskjellig slag. Tilbake er et lappeteppe av palestinske områder, hvor ikke bare helsetjenestene, men samfunnslivet på nær sagt alle områder, blir skadelidende.

\section{Oddmund Søvik}

Bergen

Oddmund Søvik (f. 1933) er dr.med. og professor emeritus ved Institutt for klinisk medisin, Universitetet i Bergen. Han har tidligere arbeidet som lege blant palestinske flyktninger i Jordan, og er medlem av Palestinakomiteen i Norge.

Ingen oppgitte interessekonflikter.

\section{Litteratur}

1. Hegna TA. Vanskelig for palestinere å få spesialistbehandling. Tidsskr Nor Legeforen 2011: 131 . $1673-5$.

\section{Piloter og legelisens}

Einar Skatteboe kommenterer i Tidsskriftet nr. 13-14/2011 (1) mitt innlegg om eldre leger og lisens (2). Jeg synes den ideen Skatteboe fremmer er meget god. Jeg kan være enig $i$ at bruk av kronologisk alder ikke er et godt kriterium på en leges evne til å fungere som lege, fordi det er så stor forskjell på kronologisk og fysiologisk aldring (3).

Kravet til en privat pilot er, kort fortalt, delt i 3: klasse/typerettighet (4), rettighetsfornyelse (5) og medisinske krav (6). Omskrevet til den aldrende lege vil tredelingen være meningsfull slik: autorisasjon, fornyelse av rettigheten til å virke $\mathrm{i}$ henhold til autorisasjonen og medisinske krav.

Hvilke krav som skal gjelde for fornyelse av rettigheten og medisinsk skikkethet kan bli en spennende diskusjon som jeg gleder meg til å delta $\mathrm{i}$.

\section{Lars Tjensvoll}

Bærum

Lars Tjensvoll (f.1956) er spesialist i allmennmedisin og fastlege. Han er oppnevnt flylege for Europa, USA og Canada og er leder i Norsk flymedisinsk forening.

Ingen oppgitte interessekonflikter.

\section{Litteratur}

1. Skatteboe E. Behandle oss som eldre piloter Tidsskr Nor Legeforen 2011; 131: 1278.

2. Tjensvoll L. Eldre piloter, yrkessjåfører - og leger. Tidsskr Nor Legeforen 2011; 131: 803

3. Engedal K. Alderdom. Store Norske Leksikon: http://snl.no/.sml_artikkel/alderdom (26.9.2011).

4. Joint Aviation Requirements-Flight Crew Licencing (JAR-FCL) 1.215-1.200: Klasserettigheter og typerettigheter. http://www.lovdata.no/cgi-wift/ ldles?doc=/sf/sf/sf-20091120-1407.htm (26.9.2011). 